\title{
$\beta$-Fructofuranosidase production by repeated batch fermentation with immobilized Aspergillus japonicus
}

\author{
S. I. Mussatto $\cdot$ L. R. Rodrigues $\cdot$ J. A. Teixeira
}

Received: 4 December 2008 / Accepted: 24 March 2009 / Published online: 25 April 2009

(C) Society for Industrial Microbiology 2009

\begin{abstract}
The fungus Aspergillus japonicus ATCC 20236 was immobilized in vegetal fiber and used in repeated batch fermentations of sucrose $(200 \mathrm{~g} / \mathrm{l})$ for the production of $\beta$-fructofuranosidases (FFase). The assays were performed during eight consecutive cycles that were completed in a total period of $216 \mathrm{~h}$. After each 24-h cycle of fermentation (except for the first cycle, which lasted $48 \mathrm{~h}$ ), the fermented broth was replaced by fresh medium, and the FFase activity was determined in the replaced medium. The average value of FFase activity was a constant $40.6 \mathrm{U} / \mathrm{ml}$ at the end of the initial seven cycles, but had decreased by $22 \%$ at the end of the eighth cycle. Concurrent with these high and constant FFase values, the hydrolyzing activity of this enzyme increased during the cycles, while the transfructosylating activity decreased. As a consequence, the maximum production of fructooligosaccharides of $134.60 \mathrm{~g} / \mathrm{l}$ observed in the initial $30 \mathrm{~h}$ of fermentation (first cycle) had gradually decreased by the end of the subsequent cycles, reaching approximately $23 \%$ of this value during cycles $4-8$. Based on these results, we conclude that the present immobilization system has a great potential for application in a semicontinuous process for the production of FFase, but further studies are necessary to maintain the FFase transfructosylation activity at high levels during the overall process.
\end{abstract}

Keywords Aspergillus $\cdot \beta$-Fructofuranosidase . Fermentation · Fructooligosaccharides · Immobilization

S. I. Mussatto $(\varangle) \cdot$ L. R. Rodrigues $\cdot$ J. A. Teixeira IBB, Institute for Biotechnology and Bioengineering, Centre of Biological Engineering, University of Minho, Campus de Gualtar, 4710-057 Braga, Portugal

e-mail: solange@deb.uminho.pt; solangemussatto@ hotmail.com

\section{Introduction}

The production and application of $\beta$-fructofuranosidades (FFase; EC.3.2.1.26) has gained tremendous practical commercial importance because these enzymes have transfructosylating activity and are able to convert the disaccharide sucrose to fructooligosaccharides (FOS), which are fructose oligomers of great industrial interest due to their functional properties and physical-chemical characteristics [1-3]. Most of these enzymes are found in fungi, such as Aspergillus, Aureobasidum, and Penicillium [4-6]. However, the yields of industrial FOS production by transfructosylation reaction are normally low (55-60\%) since FFases have, in addition to transfructosylation activity, hydrolytic activity, resulting in glucose and fructose as reaction by-products $[3,7]$. Therefore, there is a great interest in the development of a suitable and economically viable process for the industrial production of FOS that produces higher yields.

Conventionally, FOS production is a two-stage process in which the first stage is the microbial production of the enzyme by fermentation and the second stage is the enzyme reaction with sucrose (substrate) to produce FOS under controlled conditions [8]. There are a few reports on the production of FOS in a single step, i.e., based on the production of the enzyme and the enzymatic reaction in one unique fermentation process. The use of the whole cell as the biocatalyst, immobilized or not, avoids the purification of the FOS-producing enzyme from the cell extract, thereby enabling FOS production in only one step, which is less expensive [5, 9]. Moreover, immobilized cell systems have an additional advantage in that they promote an increase in the fermentor cell density that consequently contributes to increased productivity [10-12]. Therefore, such immobilized cell systems have been used in industrial-scale fermentation processes to obtain a number of different 
products, such as organic acids, edulcorant, beer, among others [13-15].

The fermentation operation mode also influences the efficiency of the process. Compared with the traditional batch operation, repeated batch, fed-batch, or continuous operating modes often improve the efficiency of the fermentation process [16]. Repeated batch cultivation is a well-known method for enhancing the productivity of microbial cultures because it skips the turnaround time and the lag phase, thus increasing the process productivity [17, 18]. This method has been a very useful approach to increase the yields of several processes, such as the production of gibberellic acid [13], hyaluronic acid [18], biohydrogen [19], and lipase [20], and may also be a promising mode for FOS fermentation.

Cell immobilization is particularly feasible for repeated batch fermentation because the process is characterized by its easy operation, convenient separation of cells from the broth, and high density of cells [16]. In addition, fermentation with immobilized cells is a convenient manner to reduce the fermentation time during repeated batch fermentation due to the elimination of the time needed for cell growth [20]. To the best of our knowledge, no reports have been published to date on repeated batch fermentation for FFase or FOS production using immobilized cells. The aim of the study reported here was to explore such a system using Aspergillus japonicus immobilized in vegetal fiber as a feasible operation strategy to increase the process yield.

\section{Materials and methods}

\section{Carrier preparation}

Vegetal fiber (Scotch Brite, 3M Spain SA) cubes $\left(0.3 \mathrm{~cm}^{3}\right)$ were used as the immobilization carrier after pre-treatment by boiling for $10 \mathrm{~min}$, washing three times with distilled water, drying overnight at $60^{\circ} \mathrm{C}$, and autoclaving at $121^{\circ} \mathrm{C}$ for $20 \mathrm{~min}$.

\section{Microorganism and fermentation conditions}

The strain A. japonicus ATCC 20236 [from Micoteca da Universidade do Minho (MUM)] was used in the experiments. The strain was maintained on potato dextrose agar (PDA; Difco; BD Diagnostics, Franklin Lakes, NJ) plates at $4^{\circ} \mathrm{C}$, and the spores were maintained mixed with glycerol solution in ultra-freezer at $-80^{\circ} \mathrm{C}$. Spores were produced by growing the strain on PDA medium at $25-30^{\circ} \mathrm{C}$ for 7-8 days.

Repeated batch fermentation experiments were carried out in 500-ml Erlenmeyer flasks containing $1 \mathrm{~g}$ of carrier and $100 \mathrm{ml}$ of culture medium [(\% w/v) sucrose 20.0 , yeast extract 2.75, $\mathrm{NaNO}_{3} 0.2, \mathrm{~K}_{2} \mathrm{HPO}_{4} 0.5, \mathrm{MgSO}_{4} \times 7 \mathrm{H}_{2} \mathrm{O}$ 0.05 , and $\mathrm{KCl} 0.05]$. Steam sterilization of the medium was carried out at $121^{\circ} \mathrm{C}$ for $20 \mathrm{~min}$. The flasks were inoculated with $1.0 \mathrm{ml}$ of a spore suspension containing around $1.8 \times 10^{7}$ spores $/ \mathrm{ml}$, which was prepared by scraping the spores from the PDA plates with a sterilized solution of $0.1 \% \mathrm{w} / \mathrm{v}$ Tween 80 and counting in a Neubauer chamber. The inoculated flasks were incubated on a rotary shaker at $28^{\circ} \mathrm{C}$ and $160 \mathrm{rpm}$ for $216 \mathrm{~h}$. After the initial $48 \mathrm{~h}$ (time of the first cycle), the fermented broth was replaced by fresh medium each $24 \mathrm{~h}$ until a total of eight cycles had been completed (216 $\mathrm{h}$ of fermentation).

\section{Sampling and analytical methodologies}

Samples for analysis were collected at the end of each cycle, filtered using $0.2-\mu \mathrm{m}$ filters, and the filtered broth was analyzed for FOS content (1-kestose, 1-nystose, and 1 - $\beta$-fructofuranosyl nystose), residual concentration of other sugars (sucrose, fructose, and glucose), $\mathrm{pH}$ and extracellular enzyme activity. The concentration of the immobilized cells was determined at the end of the fermentation period $(216 \mathrm{~h})$.

Fructooligosaccharides (1-kestose, 1-nystose, and 1- $\beta$ fructofuranosyl nystose) and other residual sugars (sucrose, glucose, and fructose) were directly analyzed by high-performance liquid chromatography (HPLC) on an LC-10 A apparatus (Jasco, Japan) with a prevail carbohydrate ES column $(5 \mu \mathrm{m}, 250 \times 4.6 \mathrm{~mm}$; Alltech, Lexington, $\mathrm{KY})$ at room temperature, and a refractive index detector. The response of the refractive index detector was recorded and integrated using the Star Chromatography Workstation software (Varian, Palo Alto, CA). A mixture of acetonitrile and $0.04 \%$ ammonium hydroxide in water $(70 / 30, \mathrm{v} / \mathrm{v})$ was used as the mobile phase at a flow rate of $1.0 \mathrm{ml} / \mathrm{min}$. Before injection, the samples were filtered through $0.2-\mu \mathrm{m}$ filters and diluted with Milli-Q water when needed. The sugars and FOS concentrations were determined from standard curves made with known concentrations of each compound. The total yield of FOS ( $Y_{\mathrm{FOS}}$ in $\mathrm{g} / \mathrm{g}$ ) was calculated as the proportion of the sum of 1-kestose $\left(Y_{\mathrm{GF} 2}\right)$, 1-nystose $\left(Y_{\mathrm{GF} 3}\right)$, and $1-\beta$-fructofuranosyl nystose $\left(Y_{\mathrm{GF} 4}\right)$ to initial sucrose concentration. The FOS productivity $\left(Q_{\mathrm{P}}\right)$ was calculated as the total FOS production $(\mathrm{g} / \mathrm{l})$ by fermentation time (h).

The $\beta$-fructofuranosidase (FFase) activity was determined by measuring the amount of glucose produced from sucrose [21]. The reaction mixture contained $100 \mathrm{ml}$ of the crude FFase extract, $300 \mathrm{mmol}$ of sucrose, and $50 \mathrm{mmol}$ of sodium acetate buffer ( $\mathrm{pH} 5.0$ ) in a total volume of $1 \mathrm{ml}$. After incubation for $20 \mathrm{~min}$ at $30^{\circ} \mathrm{C}$, the reaction was stopped by heating for $5 \mathrm{~min}$ at $100^{\circ} \mathrm{C}$. After cooling, the amount of glucose released into the supernatant was 
measured by HPLC (see above). One unit (U) of the FFase activity was defined as the amount of enzyme required to release $1 \mu \mathrm{mol}$ of glucose per minute from sucrose under the above conditions.

To determine the transfructosylating and hydrolyzing activities, we ran the reaction for $180 \mathrm{~min}$ using $0.5 \mathrm{U} / \mathrm{ml}$ of FFase in the reaction mixture described above [21]. Transfructosylating activity $\left(U_{\mathrm{t}}\right)$ and hydrolyzing activity $\left(U_{\mathrm{h}}\right)$ were determined by measuring the concentrations of 1-kestose and fructose by HPLC, respectively. One unit of transfructosylating activity was defined as the amount of enzyme required to transfer $1 \mu \mathrm{mol}$ of fructose per minute; $1 \mathrm{U}$ of hydrolyzing activity was defined as the amount of enzyme required to release $1 \mu \mathrm{mol}$ of free fructose per minute.

The amount of biomass attached to the carrier was determined after washing the support material with distilled water three times and drying at $105^{\circ} \mathrm{C}$ to a constant weight. The biomass dry weight was determined as the difference between the mycelium plus carrier and the carrier itself.

All of the fermentation experiments were conducted at least in duplicate, and the average values are reported. The relative standard deviation was less than $5 \%$.

\section{Results and discussion}

\section{Cells immobilization}

Vegetal fiber was used as the cell immobilization carrier based on a previous study in which it found to be the best carrier of six different synthetic materials tested (polyurethane foam, stainless steel sponge, pumice stones, zeolites, and foam glass) for the immobilization of $A$. japonicus during the FOS production [22]. An additional advantage is that vegetal fiber is a cheap, strong, easy-touse material that does not require any stringent or expensive pre-treatment. During this study, we found that this material can also be successfully used as an immobilization carrier in repeated batch operations, since there were no losses of material integrity over the total period of the experiments, and the immobilized cells could be effectively re-used in the following batches. In addition, the liquid phase remained clear during the whole cultivation period, which is advantageous, since a clear liquid phase reduces the mixing and mass transfer problems associated with highly viscous mycelial broths and facilitates the activities related to separation of biomass during downstream processing [23].

The fungus immobilization inside and outside of the carrier was observed to grow gradually as a dense layer on the surface, so that at the end of the fermentation period, the entire carrier was covered with biomass. At the end of the eighth cycle, the immobilized cell concentration was $8 \mathrm{~g} / \mathrm{g}$ of carrier.

\section{$\beta$-Fructofuranosidase and FOS production}

The FFase activity determined at the end of each cycle is shown in Fig. 1. During the first cycle, enzyme activity showed a steady increase, attaining a maximum value of $42.86 \mathrm{U} / \mathrm{ml}$ at the end of the cycle $(48 \mathrm{~h})$. In the subsequent seven cycles, enzyme production remained almost stable at $40.6 \mathrm{U} / \mathrm{ml}$, and this value decreased $(22 \%)$ only at the end of the eighth cycle. This is an interesting result because demonstrates an important increase in the productivity of the process. By re-using the immobilized cells, the time necessary for the initial microorganism growth (around 6 days) is eliminated, thereby resulting in a considerable improvement in fermentation productivity. This result indicates that the 8 days are necessary to produce FFase in individual batch operations ( 6 days for microorganism growth and 2 days of fermentation), which means a total of 42 uninterrupted days would be necessary to complete seven batches; this could be reduced to only 14 days by performing repeated batch fermentation with immobilized cells.

However, the production of FOS did not show the same behavior that that observed for FFase. As can be seen in Fig. 2, the maximum FOS concentration was obtained in the initial $30 \mathrm{~h}$ of fermentation (first cycle), corresponding to $134.60 \mathrm{~g} / 1$ ( $68.38 \mathrm{~g} / 1$ 1-kestose, $57.63 \mathrm{~g} / \mathrm{l}$ 1-nystose, $8.59 \mathrm{~g} / 11-\beta$-fructofuranosyl nystose). Thereafter, the total concentration of such compounds fell due to the exhaustion of sucrose in the media and the conversion of 1-kestose into FOS of longer chains. At the end of the first fermentation cycle, the total FOS concentration was $54 \%$ of the maximum attained. Replacing the fermented broth by fresh

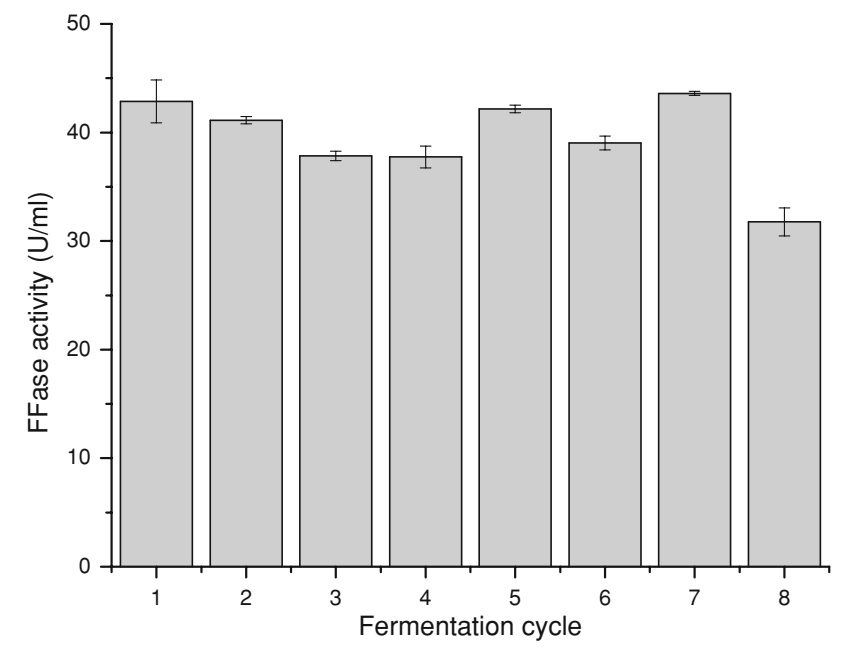

Fig. $1 \beta$-Fructofuranosidase (FFase) activity during repeated batch fermentation of sucrose by Aspergillus japonicus immobilized in vegetal fiber 


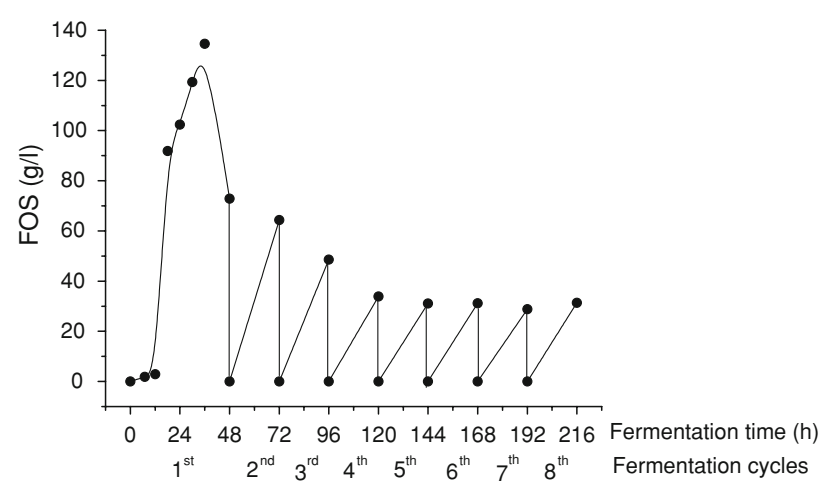

Fig. 2 Fructooligosaccharide $(F O S)$ production during repeated batch fermentation of sucrose by $A$. japonicus immobilized in vegetal fiber

medium resulted in a maximum FOS production in the second cycle that was only $11.75 \%$ lower than that achieved in the first cycle; as the fermentation time was twice as short $(24 \mathrm{~h})$, this resulted in a higher FOS productivity (Table 1). For the subsequent cycles, the total FOS concentration obtained at the end of each 24-h cycle was lower, with similar values for cycles 4-8. A similar decreasing trend in the final production level was also observed during the repeated batch fermentation for gibberellic acid production by immobilized cells of Fusarium moniliforme [13]. According to the authors of that report, such a decrease may be a result of the increase in the number of immobilized dead cells as a result of the re-use. Another possible explanation is given by Liu and Liu [16], who said that the residual metabolic by-products in the cells, such as ethanol, acetic acid, and others, may have a negative effect on the following cycles of the repeated batch operation and that the production rates can be improved when recycled cells are washed before further re-use.

Although the FOS productivity values were not so different for the different cycles (except for the second), FOS yield was low for all of them (Table 1), given that FOS are produced on industrial scale with yields of about 55-60\% $[3,7]$. It is interesting to note that the FOS production was low but that the sucrose was practically exhausted in all of the fermentation cycles. This means that the carbon source could have been used in higher amounts for the cell growth than for the production of FOS. In fact, we was found a constant biomass increase during the running time. At the end of the first cycle ( $48 \mathrm{~h}$ fermentation), the immobilized cell mass was $1.25 \mathrm{~g} / \mathrm{g}$ carrier, while at the end of the fermentation period $(216 \mathrm{~h})$, the immobilized mass corresponded to $8 \mathrm{~g} / \mathrm{g}$ carrier.

Some authors have observed that high cellular growth of the fungus strains results in more carbon and nitrogen being used for cellular mass, thereby decreasing enzyme production [24]. In fact, extent growth can lead to limitations in mass transfer operations, causing diffusional limitation of
Table 1 Fermentation parameters of fructooligosaccharide (FOS) production by Aspergillus japonicus during repeated batch process using cells immobilized in vegetal fiber

\begin{tabular}{llll}
\hline Cycles & $Y_{\mathrm{P} / \mathrm{S}}$ total $(\mathrm{g} / \mathrm{g})^{\mathrm{a}}$ & $Y_{\mathrm{P} / \mathrm{S}}$ consumed $(\mathrm{g} / \mathrm{g})^{\mathrm{b}}$ & $Q_{\mathrm{P}}(\mathrm{g} / \mathrm{l} . \mathrm{h})^{\mathrm{c}}$ \\
\hline First & 0.34 & 0.35 & 1.52 \\
Second & 0.30 & 0.32 & 2.68 \\
Third & 0.23 & 0.24 & 2.03 \\
Fourth & 0.16 & 0.16 & 1.41 \\
Fifth & 0.15 & 0.15 & 1.30 \\
Sixth & 0.15 & 0.15 & 1.30 \\
Seventh & 0.13 & 0.14 & 1.20 \\
Eight & 0.15 & 0.15 & 1.31 \\
\hline
\end{tabular}

${ }^{a}$ FOS yield factor as the ratio between total FOS produced and initial sucrose concentration

${ }^{\mathrm{b}}$ FOS yield factor as the ratio between total FOS produced and sucrose consumed

${ }^{c}$ FOS productivity as the ratio between FOS produced per fermentation time

the substrate into the film, which may reduce the specific productivity of the biofilm $[25,26]$. A maximum value of cell loading per unit area exists for an optimal value of catalytic activity, and the catalytic efficiency can decrease exponentially with increased cell loading. The possible upper limit depends on the type of cell and the matrix; for example, during gluconic acid production using A. niger immobilized on cellulose microfibrils, the optimal mycelial density on the support was $2.4 \mathrm{~g} / \mathrm{support}$, and the specific productivity dropped off on either side of this density level [26]. The immobilized cell concentration in our study achieved a much higher level and could have affected the process productivity.

Nevertheless, in our study, the FFase presented high activity for the initial seven cycles. This results necessitated an evaluation of the levels of transfructosylating $\left(U_{\mathrm{t}}\right)$ and hydrolyzing $\left(U_{\mathrm{h}}\right)$ activities of this enzyme at the end of each cycle. The FFases commonly possess both $U_{\mathrm{t}}$ and $U_{\mathrm{h}}$ activities; however, the greater the ratio between $U_{\mathrm{t}}$ and $U_{\mathrm{h}}$, the greater the production of FOS [27]. In our study, the maximum $U_{\mathrm{t}} / U_{\mathrm{h}}$ ratio (4.82) was achieved at the end of the first cycle. This value was not maintained during the subsequent cycles since we observed a gradual increase in $U_{\mathrm{h}}$ activity, which reduced the $U_{\mathrm{t}} / U_{\mathrm{h}}$ ratio until it reached a value of only 0.40 at the end of the eighth cycle. This would explain the low production of FOS obtained in the experiments, since FFases with low $U_{\mathrm{t}} / U_{\mathrm{h}}$ ratios hydrolyze the FOS produced at the end of the reaction period [27].

Some factors affecting the $U_{\mathrm{t}} / U_{\mathrm{h}}$ ratio of FFases are reported to be the strains themselves, the substrate concentration, and reaction conditions, such as $\mathrm{pH}$ and temperature [28]. More information on the biochemical characteristics of FFase could be helpful to determine one condition for which the FOS content is optimum. 


\section{Conclusions}

$\beta$-fructofuranosidase production by repeated batch fermentation of sucrose using A. japonicus immobilized in vegetal fiber is a process with great potential for industrial application, since the microorganism was able to adhere totally in the carrier, thereby facilitating its re-use in subsequent fermentation batches, and the activity of the enzyme was elevated during seven consecutive cycles, thus increasing the process productivity. However, further studies are needed to optimize this process so that the FFase transfructosylation activity can be maintained at high levels during the overall batches, thereby enabling maximum FOS yield and productivity during several fermentation cycles. The time to replace the medium, the volume of the replaced medium, and its optimal composition are variables that affect the efficiency of repeated batch fermentations, and these should be optimized to increase the process yield [20]. However, considering that this is the first report on the production of FFase and FOS by repeated batch fermentation with fungus immobilized cells, the results obtained here are very promising and open up new possibilities for developing a novel process with a potential for synthesizing both products at the industrial level.

Acknowledgments The financial support from FCT, the Portuguese Foundation for Science and Technology (research project SFRH/BPD/ $38212 / 2007$ ) is gratefully acknowledged.

\section{References}

1. Mussatto SI, Mancilha IM (2007) Non-digestible oligosaccharides: a review. Carbohydr Polym 68:587-597. doi:10.1016/ j.carbpol.2006.12.011

2. Sangeetha PT, Ramesh MN, Prapulla SG (2005) Recent trends in the microbial production, analysis and application of fructooligosaccharides. Trends Food Sci Technol 16:442-457. doi:10.1016/ j.tifs.2005.05.003

3. Yun JW (1996) Fructooligosaccharides-occurrence, preparation, and application. Enzyme Microb Technol 19:107-117. doi:10.1016/ 0141-0229(95)00188-3

4. Balasubramaniem AK, Nagarajan KV, Paramasamy G (2001) Optimization of media for beta-fructofuranosidase production by Aspergillus niger in submerged and solid state fermentation. Process Biochem 36:1241-1247. doi:10.1016/S0032-9592(01) 00166-2

5. Chien C-S, Lee W-C, Lin T-J (2001) Immobilization of Aspergillus japonicus by entrapping cells in gluten for production of fructooligosaccharides. Enzyme Microb Technol 29:252-257. doi:10.1016/S0141-0229(01)00384-2

6. Ghazi I, Gómez de Segura A, Fernández-Arrojo L, Alcalde M, Yates M, Rojas-Cervantes ML, Plou FJ, Ballesteros A (2005) Immobilisation of fructosyltransferase from Aspergillus aculeatus on epoxy-activated sepabeads EC for the synthesis of fructo-oligosaccharides. J Mol Catal B Enzym 35:19-27. doi:10.1016/ j.molcatb.2005.04.013

7. Nishizawa K, Nakajima M, Nabetani H (2001) Kinetic study on transfructosylation by $\beta$-fructofuranosidase from Aspergillus niger ATCC 20611 and availability of a membrane reactor for fructooligosaccharide production. Food Sci Technol Res 7:39-44. doi:10.3136/fstr.7.39

8. Sangeetha PT, Ramesh MN, Prapulla SG (2005) Maximization of fructooligosaccharide production by two stage continuous process and its scale up. J Food Eng 68:57-64. doi:10.1016/j.jfoodeng. 2004.05.022

9. Cruz R, Cruz VD, Belini MZ, Belote JG, Vieira CR (1998) Production of fructooligosaccharides by the mycelia of Aspergillus japonicus immobilized in calcium alginate. Bioresour Technol 65:139-143. doi:10.1016/S0960-8524(98)00005-4

10. Cohen Y (2001) Biofiltration--the treatment of fluids by microorganisms immobilized into the filter bedding material: a review. Bioresour Technol 77:257-274. doi:10.1016/S0960-8524(00) 00074-2

11. Fenice M, Giambattista RD, Raetz E, Leuba J-L, Federici F (1998) Repeated-batch and continuous production of chitinolytic enzymes by Penicillium janthinellum immobilized on chemicallymodified macroporous cellulose. J Biotechnol 62:119-131. doi:10.1016/S0168-1656(98)00051-0

12. Santos JC, Mussatto SI, Dragone G, Converti A, Silva SS (2005) Evaluation of porous glass and zeolite as cells carriers for xylitol production from sugarcane bagasse hydrolysate. Biochem Eng J 23:1-9. doi:10.1016/j.bej.2004.10.001

13. Meleigy SA, Khalaf MA (2009) Biosynthesis of gibberelic acid from milk permeate in repeated batch operation by a mutant Fusarium moliniforme cells immobilized on loofa sponge. Bioresour Technol 100:374-379. doi:10.1016/j.biortech.2008.06.024

14. Silva SS, Mussatto SI, Santos JC, Santos DT, Polizel J (2007) Cell immobilization and xylitol production using sugarcane bagasse as raw material. Appl Biochem Biotechnol 141:215-227. doi:10.1007/ BF02729063

15. Dragone G, Mussatto SI, Almeida e Silva JB (2007) High gravity brewing by continuous process using immobilised yeast: effect of wort original gravity on fermentation performance. J Inst Brew 113:391-398

16. Liu Y, Liu D (2004) Kinetic study on glycerol production by repeated batch fermentation using free Candida krusei. Process Biochem 39:1507-1510. doi:10.1016/S0032-9592(03)00280-2

17. Radmann EM, Reinehr CO, Costa JAV (2007) Optimization of the repeated batch cultivation of microalga Spirulina platensis in open raceway ponds. Aquaculture 265:118-126. doi:10.1016/j.aquaculture.2007.02.001

18. Huang W-C, Chen S-J, Chen T-L (2008) Production of hyaluronic acid by repeated batch fermentation. Biochem Eng J 40:460-464. doi:10.1016/j.bej.2008.01.021

19. Liu DW, Zeng RJ, Angelidaki I (2008) Enrichment and adaptation of extreme-thermophilic $\left(70^{\circ} \mathrm{C}\right)$ hydrogen producing bacteria to organic household solid waste by repeated batch cultivation. Int J Hydrogen Energy 33:6492-6497. doi:10.1016/j.ijhydene.2008. 08.014

20. Yang X, Wang B, Cui F, Tan T (2005) Production of lipase by repeated batch fermentation immobilized Rhizopus arrhizus. Process Biochem 40:2095-2103. doi:10.1016/j.procbio.2004. 07.015

21. Yoshikawa J, Amachi S, Shinoyama H, Fujii T (2006) Multiple $\beta$-fructofuranosidases by Aureobasidium pullulans DSM2404 and their roles in fructooligosaccharide production. FEMS Microbiol Lett 265:159-163. doi:10.1111/j.1574-6968.2006.00488.x

22. Mussatto SI, Aguilar CN, Rodrigues LR, Teixeira JA (2009) Colonization of Aspergillus japonicus on synthetic materials and application to the production of fructooligosaccharides. Carbohydr Res 344:795-800. doi:10.1016/j.carres.2009.01.025

23. Gawande PV, Kamat MY (1998) Immobilization of Aspergillus sp on nylon bolting cloth for production of xylanase. J Ferment Bioeng 86:243-246. doi:10.1016/S0922-338X(98)80122-0 
24. Dorta C, Cruz R, Oliva-Neto P, Moura DJC (2006) Sugarcane molasses and yeast powder used in the fructooligosaccharides production by Aspergillus japonicus-FCL 119T and Aspergillus niger ATCC 20611. J Ind Microbiol Biotechnol 33:1003-1009. doi:10.1007/s10295-006-0152-x

25. Buchholz K (1992) Immobilized enzymes: kinetics, efficiency, and applications. Intern Chem Eng 32:1-13

26. Sankpal NV, Kulkarni BD (2002) Optimization of fermentation conditions for gluconic acid production using Aspergillus niger immobilized on cellulose microfibrils. Process Biochem 37:13431350. doi:10.1016/S0032-9592(01)00335-1

27. Hidaka K, Hirayama M, Sumi N (1988) A fructooligosaccharideproducing enzyme from Aspergillus niger ATCC 20611. Agric Biol Chem 52:1181-1187

28. Chen W-C, Liu C-H (1996) Production of $\beta$-fructofuranosidase by Aspergillus japonicus. Enzyme Microb Technol 18:153-160. doi:10.1016/0141-0229(95)00099-2 